\title{
Transdifferentiation potential of adipose-derived stem cells into neural lineage and their application
}

\author{
Nazem Ghasemi and Shahnaz Razavi* \\ *Correspondence: razavi@med.mui.ac.ir

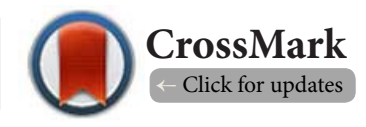 \\ Department of Anatomical Science and Molecular Biology, School of Medicine, Isfahan University of Medical Sciences, Isfahan, Iran.
}

\begin{abstract}
Adipose-derived stem cells are a kind of mesenchymal stem cells which have a higher frequency in the adipose tissue and can be harvested by minimally invasive procedures. These cells are able to differentiate into other cells outside their lineage such as neuron, neurotrophic factor secreting cells and Schwann cells. Many of the identified neurotrophic factors such as brain-derived neurotrophic factor, nerve growth factor, and glial cell line-derived neurotrophic factor can be produced by adipose-derived stem cells. In addition, these cells when differentiated into neurotrophic factor secreting cells are able to secrete a significantly high level of these factors. Neurotrophic factors have a significant role in cellular processes include cell proliferation, differentiation and maturation. This article reviews the in vitro differentiation of adiposederived stem cells into neural lineage cells and clinical application.
\end{abstract}

Keywords: Adipose-derived stem cells, neurogenic differentiation, schwann cells, neurotrophic factor secreting cells

\section{Introduction}

Stem cells are a population of undifferentiated cells that characterized by their self-renewal ability and multi-potency. So, these cells can create more stem cells and other specialized cells. Generally, there are two kinds of stem cells including embryonic stem cells, which are segregated from the inner cell mass of embryo, and non embryonic stem cells, which are found in various tissues especially in bone marrow. Mesenchymal stem cells (MSCs) are a kind of non embryonic stem cells that can be isolated from various tissues [1], such as bone marrow and blood [2], amniotic fluid [3], dermis [4], umbilical cord blood [5], and in tissues that contain fat [6].

Adipose-derived stem cells (ADSCs) that were first identified in 2001 [7], are a population of mesenchymal stem cells which have a much higher frequency in the fat tissue than in bone marrow (about $8 \times 10^{4}$ to $3.5 \times 10^{5} \mathrm{ADSC}$ per gram fat that is approximately 500-fold more) [8-10]. These cells can be isolated by less invasive procedures but they are not homogenous population cells [11]. In the human body, there are two types of adipose tissue including white and brown which are morphologically and functionally different. Moreover, white fat has greater distribution than other type. Previous studies have shown that ADSCs isolated from these tissues (visceral or superficial layers) have different characteristics [12]. For example, the proliferation of ADSCs isolated from superficial layers is high faster than those from the visceral layer [13]. Therefore, ADSCs isolated from both layers express similar levels of the growth factors and some of the stem cell markers such as oct 4 and nanog (Kalbermatten et al., 2011). In our previous studies, flow cytometry analysis showed that ADSCs express typical mesenchymal markers such as CD90, CD44, CD105, and are negative for hematopoietic antigens such as CD34, CD45, and CD14 [14-17]. Many of the identified nerve growth factors such as brain-derived neurotrophic factor (BDNF), nerve growth factor (NGF) and glial cell line-derived neurotrophic factor (GDNF) can be produced by ADSCs $[13,14]$. Therefore, ADSCs are considered to be a mediator of tissue regeneration through paracrine effects by modulating angiogenesis, promoting anti-ischemic effects, and neuroprotective effects [18].

ADSCs when cultured in the appropriate conditions are capable to differentiate into other cells outside their lineage such as neuronal, glial and neurotrophic factors secreting cells (NTFs) [14-16,19-24] (Figure 1). Thus, offers the potential to tissue maintenance and regeneration. This review focused on in vitro differentiation of ADSCs to neural lineage cells.

\section{Review}

Transdifferentiation potential of ADSCs into neuron cells and clinical application

Nervous tissue is the main component of the central and peripheral 

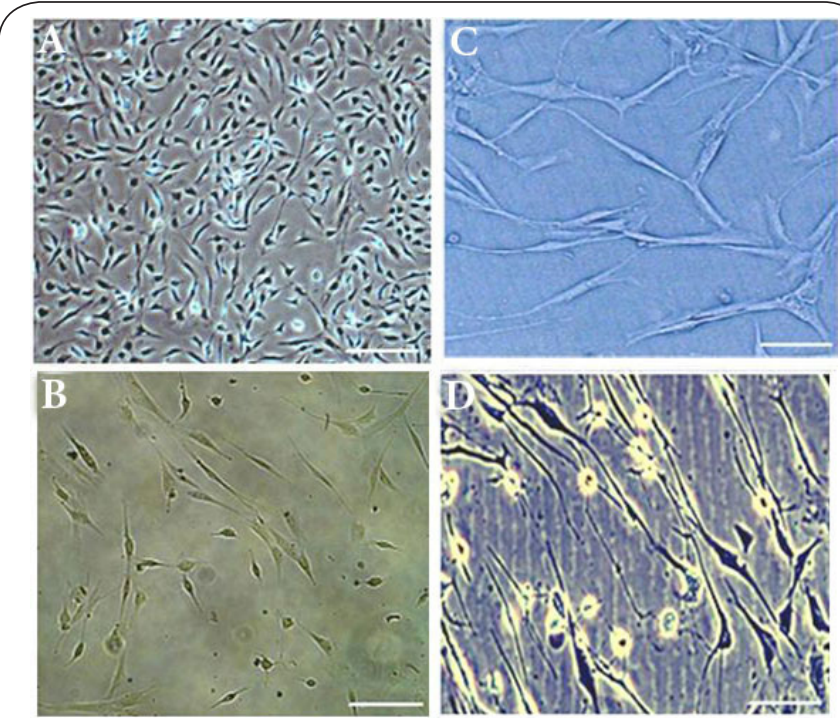

Figure 1. Transdifferentiation potential of adipose-derived stem cells into neural lineage cells. Phase contrast image of human adipose-derived stem cells (A), Neuron cells (B), Schwann cells (C), neurotrophic factor (NTF)-secreting cells following differentiation (D); Scale bar: A=100 $\mu \mathrm{m}, \mathrm{B}, \mathrm{C}$, $\mathrm{D}=150 \mu \mathrm{m}$.

nerve system which contains specialized cells including neurons and neuroglia that regulate body functions. Furthermore, neural stem cells (NSCs) which are self-renewing and multi-potent cells can be isolated from this tissue. These cells are a type of adult stem cells that under special stimulation can be differentiated into neurons or glial cells which capable to generate nervous tissues during development and to repair damaged area after injury. It is important to mention that NSCs isolation from neural tissue is an impossible process. However, other resources of stem cell have been proposed for treatment in the field of neurodegenerative diseases.

Most of the studies focused on ADSCs because these cells are capable to differentiate to cells of ectodermal, mesodermal and endodermal lineage $[6,25,26]$. In addition, ADSCs possess additional characteristics including immunomodulatory properties that can alter the cytokine secretion profile of immune cells and act as source of variety of growth factors. In according to our previous study, in vitro differentiation of ADSCS into neuron cells is achieved by culture with media containing selective lineage specific induction factors [21].

Recently, stem cell-based therapies using ADSCs are sugg ested as a potential novel paradigm for the treatment of neural tissue injuries. ADSCs by neurotrophic factors secretion have the ability to protect neuronal population (by BDNF and neuro-trophin (NT)-3 secretion), enhance neuronal survival (by BDNF, NGF, NT3 and neurotrophin (NT)-4 secretion), and promote axon regeneration [27-30]. Luo et al., reported that transforming growth factor beta 1 (TGF $\beta 1$ ) enhanced the regenerative capacity of ADSCs transplanted by protecting these cells from apoptosis and decreasing inflammation and promoting vascular endothelial growth factor (VEGF dependent angiogenesis [30].

Another study's results demonstrated that implanted ADSCs into the lumen of polycaprolactone (PCL)-based nerve conduits in peripheral nerve injury capable to promote the nerve formation [31]. The same group demonstrated that ADSC are capable to alleviate symptoms of Alzheimer's disease and diminish cognitive decline through modulate microglial activation [32]. Chen et al., revealed that ADSCs transplantation in rat model of brain ischemia can promote neuronal regeneration by inhibiting the expression of Glial fibrillary acidic protein (GFAP) and increasing the expressions of Neuritin and NF-200 in the brain [33].

\section{Transdifferentiation potential of ADSCs into Schwann cells and clinical application}

Schwann cells (SCs) are the chief glia cell in the peripheral nervous system (PNS) which play a major function in many important aspects of peripheral nerve biology including nerve development and neurodegenerative processes [34,35]. Moreover, SCs possess additional performance including generation of the nerve extracellular matrix, regulate of neuromuscular synaptic activity, offering of antigens to immune cells and trophic support for neurons through neurotrophic factors secretion [34,37].

After peripheral nerve injury, SCs are necessary for nerve regeneration and according to previous published data, transplanted Schwann cells can remyelinate and restore neural function [38,39]. Unfortunately, autologous SCs isolation is an invasive procedure and it is difficult to get sufficient number of SCs for clinical application. However, recent studies demonstrated that ADSCs seems to be one ideal cell source for transdifferentiation into SCs [40]. In our previous study, using a standard protocol, ADSCs were induced into SCs [22].

There are a large number of experimental studies showing positive effects of SCs transplantation as a therapy for neurodegenerative disease and for spinal cord injury [41-43].

Yang et al., demonstrated that simultaneous transplantation of Schwann cells and ADSC can effectively promote locomotor functional recovery and diminish reactive gliosis after contusion brain injury in rats [44]. In addition, Kanno et al., in their study concluded that the combination of SC transplants engineered to secrete neurotrophin and chondroitinase further improves axonal regeneration and sensorimotor function [45]. In our previous study, we indicated that ADSC are a good option to induce SCs-like for transplantation in demyelinating disease [22]. Moreover, these cells were able to generate components of myelin shell when exposed to Leukemia inhi-bitory factor (LIF) [24]. Thus, these cells are a potential cell source for the treatment of nerve injuries in central nervous system (CNS) and PNS.

Mantovani et al., illustrated that ADSCs can differentiate into SCs lineage which have functional properties and growth factor synthesis activities alike native SC [46]. Thus, during nerve 
regeneration, these cells could prepare nerve fiber support and promote locomotors functional recovery.

In a previous study, human ADSCs (hADSCs) differentiated into Schwann-like cells by a mixture of glial growth factors and then assessed their ability to act as Schwann cells in vitro and in vivo. The results of this study showed that hADSCs can differentiate into SC-like cells and have ability to secrete neurotrophic factors as well as to form components of myelin shell in vivo. So, hADSCs may be an interesting prospect for cellbased transplantation therapy for various nerve disorders [47].

In another study, adipose derived stem cells of different anatomical regions, differentiated into Schwann-like cells. Finally it was concluded that the differentiated cells had a same features and function to primary Schwann cells in vitro. So, this would support the application of autologous transplantation of these cells for therapeutic delivery and potential treatment of nerve injuries [48].

\section{Transdifferentiation potential of ADSCs into Neurotrophic factor secreting cells and clinical application}

Neurotrophic factor secreting cells (NTF-SCs) by secreting a large amount of neurotrophic factors that are necessary for neuronal development and survival, paves the way to use NTFs cells for the treatment of patients that suffering from neurodegenerative disease. Neurotrophic factors are small molecule polypeptides including NGF family, GDNG family ligands and neuropoietic cytokines [29]. These factors have a significant role in regulating of neuronal development in the PNS and CNS through intracellular signaling by specific receptors.

The application of neurotrophic factors as therapeutic agents is a new idea for preserving and restoring neuronal function during neurodegenerative disorders. Contrary to this view, since the half-life of these agents is low, direct application of them is limited [49]. Moreover, when delivered peripherally, theirs efficacy diminished due to the blood-brain barrier. So, transplantation of NTF-SCs instead of neurotrophic factors may be an ideal strategy for delivering neurotrophic factors into the neural tissue. In our previous study, the results demonstrated that ADSC are able to secrete a variety of growth factors that strongly supporting the process of neuronal differentiation. In addition, NTF-SCs derived from ADSCs are able to secrete more of these factors [14]. Therefore, NTF-SCs can be transplanted safely into neural lesions and thereby serve as vehicles for delivering NTFs. ADSCs can be differentiated into NTF-SCs when cultured in NTF-SCs differentiation media. This induction can be done according to our previous method [23].

Recent studies have shown that NTF-SCs transplantation can efficiently improve the symptoms of some types of neurodegenerative diseases [50-52]. Thus, these cells may be an ideal cell source for cell based therapy in neurodegenerative diseases.

Sadan et al [53]. Evaluated the migration ability and efficacy of neurotrophic factor-secreting cells in animal models of
Parkinson's and Huntington's disease. In this study by a twophase medium-based induction, mesenchymal stem cells were differentiated into NTF-SCs and then these cells transplanted into induced striatal lesions. The histological evaluation demonstrated that the transplanted cells migrated and acted to regenerate the damaged nerve cells. Therefore, these finding showed that the induced MSCs may be a potential therapy in the treatment of neurodegenerative diseases due to their paracrine effects and their ability to migrate towards the lesions.

\section{Conclusion}

ADSCs are a promising cell source for neural regenerative due to their ability to differentiate into neural lineages cells, and ability to secrete various neurotrophic factors. A large number of clinical examinations using ADSCs have already performed and many of them showed ADSCs are effective on neural tissue regeneration.

\section{List of abbreviations}

ADSCs: Adipose-derived stem cells

BDNF: Brain-derived neurotrophic factor

CNS: Central nervous system

GDNF: Glial cell line-derived neurotrophic factor

GFAP: Glial fibrillary acidic protein

hASCs: Human adipose-derived stem cells

LIF: Leukemia inhibitory factor

MSCs: Mesenchymal stem cells

NSCs: Neural stem cells

NTF-SCs: Neurotrophic factor secreting cells

NGF: Nerve growth factor

NT: Neurotrophin

PCL: Polycaprolactone

PNS: Peripheral nervous system

SCs: Schwann cells

TGF $\beta 1$ :Transforming growth factor beta 1

VEGF: Vascular endothelial growth factor

\section{Competing interests}

The authors declare that they have no competing interests.

Authors' contributions

\begin{tabular}{|l|c|c|}
\hline Authors' contributions & NG & SR \\
\hline Research concept and design & -- & $\checkmark$ \\
\hline Collection and/or assembly of data & -- & $\checkmark$ \\
\hline Data analysis and interpretation & -- & -- \\
\hline Writing the article & $\checkmark$ & -- \\
\hline Critical revision of the article & $\checkmark$ & -- \\
\hline Final approval of article & -- & $\checkmark$ \\
\hline
\end{tabular}

\section{Acknowledgement}

The authors are grateful to Iranian Council of Stem Cell Technology, Isfahan University of Medical Sciences for their support.

\section{Publication history}

EIC: Giuseppe Musumeci, University of Catania, Italy.

Received: 20-Oct-2014 Final Revised: 03-Nov-2014

Accepted: 05-Nov-2014 Published: 12-Nov-2014 


\section{References}

1. da Silva Meirelles L, Chagastelles PC and Nardi NB. Mesenchymal stem cells reside in virtually all post-natal organs and tissues. J Cell Sci. 2006; 119:2204-13. | Article I PubMed

2. Dezawa M, Takahashi I, Esaki M, Takano M and Sawada H. Sciatic nerve regeneration in rats induced by transplantation of in vitro differentiated bone-marrow stromal cells. Eur J Neurosci. 2001; 14:1771-6. | Article | PubMed

3. Sessarego N, Parodi A, Podesta M, Benvenuto F, Mogni M, Raviolo V, Lituania M, Kunkl A, Ferlazzo G, Bricarelli FD, Uccelli A and Frassoni F. Multipotent mesenchymal stromal cells from amniotic fluid: solid perspectives for clinical application. Haematologica. 2008; 93:339-46. | Article | PubMed

4. Haniffa MA, Wang XN, Holtick U, Rae M, Isaacs JD, Dickinson AM, Hilkens CM and Collin MP. Adult human fibroblasts are potent immunoregulatory cells and functionally equivalent to mesenchymal stem cells. J Immunol. 2007; 179:1595-604. | Article | PubMed

5. Erices $\mathrm{A}$, Conget $\mathrm{P}$ and Minguell JJ. Mesenchymal progenitor cells in human umbilical cord blood. Br J Haematol. 2000; 109:235-42. | Article I PubMed

6. Zuk PA, Zhu M, Mizuno H, Huang J, Futrell JW, Katz AJ, Benhaim P, Lorenz HP and Hedrick MH. Multilineage cells from human adipose tissue: implications for cell-based therapies. Tissue Eng. 2001; 7:211-28. | Article I PubMed

7. Zuk PA, Zhu M, Ashjian P, De Ugarte DA, Huang Jl, Mizuno H, Alfonso ZC, Fraser JK, Benhaim $\mathrm{P}$ and Hedrick $\mathrm{MH}$. Human adipose tissue is a source of multipotent stem cells. Mol Biol Cell. 2002; 13:4279-95. | Article | PubMed Abstract | PubMed Full Text

8. von Heimburg D, Hemmrich K, Haydarlioglu S, Staiger $\mathrm{H}$ and Pallua N. Comparison of viable cell yield from excised versus aspirated adipose tissue. Cells Tissues Organs. 2004; 178:87-92. I Article I PubMed

9. Fraser JK, Wulur I, Alfonso Z and Hedrick MH. Fat tissue: an underappreciated source of stem cells for biotechnology. Trends Biotechnol. 2006; 24:150-4. I Article I PubMed

10. Parker AM and Katz AJ. Adipose-derived stem cells for the regeneration of damaged tissues. Expert Opin Biol Ther. 2006; 6:567-78. | Article | PubMed

11. Li H, Zimmerlin L, Marra KG, Donnenberg VS, Donnenberg AD and Rubin JP. Adipogenic potential of adipose stem cell subpopulations. Plast Reconstr Surg. 2011; 128:663-72. | Article I PubMed Abstract | PubMed Full Text

12. Tsuji W, Rubin JP and Marra KG. Adipose-derived stem cells: Implications in tissue regeneration. World J Stem Cells. 2014; 6:312-21. I Article | PubMed Abstract | PubMed Full Text

13. Kalbermatten DF, Schaakxs D, Kingham PJ and Wiberg M. Neurotrophic activity of human adipose stem cells isolated from deep and superficial layers of abdominal fat. Cell Tissue Res. 2011; 344:251-60. | Article | PubMed

14. Razavi S, Razavi MR, Zarkesh Esfahani H, Kazemi M and Mostafavi FS Comparing brain-derived neurotrophic factor and ciliary neurotrophic factor secretion of induced neurotrophic factor secreting cells from human adipose and bone marrow-derived stem cells. Dev Growth Differ. 2013; 55:648-55. | Article | PubMed

15. Razavi S, Jahromi M, Amirpour N and Khosravizadeh Z. Effect of sertraline on proliferation and neurogenic differentiation of human adipose-derived stem cells. Adv Biomed Res. 2014; 25:97. | Article | PubMed Abstract I PubMed Full Text

16. Ghasemi N, Razavi S, Mardani M, Esfandiari E, Salehi H and Zarkesh Esfahani SH. Transplantation of human adipose-derived stem cells enhances remyelination in lysolecithin-induced focal demyelination of rat spinal cord. Mol Biotechnol. 2014; 56:470-8. I Article I PubMed

17. Mostafavi FS, Razavi S, Mardani M, Esfandiari E, Esfahani HZ and Kazemi M. Comparative Study of Microtubule-associated Protein-2 and Glial Fibrillary Acidic Proteins during Neural Induction of Human Bone Marrow Mesenchymal Stem Cells and Adipose-Derived Stem Cells. Int J Prev Med. 2014; 5:584-95. | PubMed Abstract | PubMed Full Text
18. Lee HC, An SG, Lee HW, Park JS, Cha KS, Hong TJ, Park JH, Lee SY, Kim SP, Kim YD, Chung SW, Bae YC, Shin YB, Kim JI and Jung JS. Safety and effect of adipose tissue-derived stem cell implantation in patients with critical limb ischemia: a pilot study. Circ J. 2012; 76:1750-60. | Article | PubMed

19. Kingham PJ, Kalbermatten DF, Mahay D, Armstrong SJ, Wiberg M and Terenghi G. Adipose-derived stem cells differentiate into a Schwann cell phenotype and promote neurite outgrowth in vitro. Exp Neurol. 2007; 207:267-74. | Article I PubMed

20. Kingham PJ, Mantovani $C$ and Terenghi G. Notch independent signalling mediates Schwann cell-like differentiation of adipose derived stem cells. Neurosci Lett. 2009; 467:164-8. I Article I PubMed

21. Ahmadi N, Razavi S, Kazemi M and Oryan S. Stability of neural differentiation in human adipose derived stem cells by two induction protocols. Tissue Cell. 2012; 44:87-94. I Article I PubMed

22. Razavi S, Ahmadi N, Kazemi M, Mardani M and Esfandiari E. Efficient transdifferentiation of human adipose-derived stem cells into Schwannlike cells: A promise for treatment of demyelinating diseases. Adv Biomed Res. 2012; 1:12. I Article I PubMed Abstract I PubMed Full Text

23. Razavi S, Razavi MR, Kheirollahi-Kouhestani M, Mardani M and Mostafavi FS. Co-culture with neurotrophic factor secreting cells induced from adipose-derived stem cells: promotes neurogenic differentiation. Biochem Biophys Res Commun. 2013; 440:381-7. | Article I PubMed

24. Razavi S, Mardani M, Kazemi M, Esfandiari E, Narimani M, Esmaeili A and Ahmadi N. Effect of leukemia inhibitory factor on the myelinogenic ability of Schwann-like cells induced from human adipose-derived stem cells. Cell Mol Neurobiol. 2013; 33:283-9. | Article I PubMed

25. Timper K, Seboek D, Eberhardt M, Linscheid P, Christ-Crain M, Keller U, Muller $\mathrm{B}$ and Zulewski $\mathrm{H}$. Human adipose tissue-derived mesenchymal stem cells differentiate into insulin, somatostatin, and glucagon expressing cells. Biochem Biophys Res Commun. 2006; 341:1135-40. | Article | PubMed

26. Radtke C, Schmitz B, Spies M, Kocsis JD and Vogt PM. Peripheral glial cell differentiation from neurospheres derived from adipose mesenchymal stem cells. Int J Dev Neurosci. 2009; 27:817-23. | Article I PubMed

27. Villoslada P, Hauser SL, Bartke I, Unger J, Heald N, Rosenberg D, Cheung SW, Mobley WC, Fisher S and Genain CP. Human nerve growth factor protects common marmosets against autoimmune encephalomyelitis by switching the balance of T helper cell type 1 and 2 cytokines within the central nervous system. J Exp Med. 2000; 191:1799-806. | Article | PubMed Abstract | PubMed Full Text

28. Blesch A and Tuszynski MH. Cellular GDNF delivery promotes growth of motor and dorsal column sensory axons after partial and complete spinal cord transections and induces remyelination. J Comp Neurol. 2003; 467:403-17. I Article I PubMed

29. Kerschensteiner M, Stadelmann C, Dechant G, Wekerle H and Hohlfeld R. Neurotrophic cross-talk between the nervous and immune systems: implications for neurological diseases. Ann Neurol. 2003; 53:292-304. | Article I PubMed

30. Luo $\mathrm{H}$, Zhang $\mathrm{Y}$, Zhang $\mathrm{Z}$ and Jin $\mathrm{Y}$. The protection of MSCs from apoptosis in nerve regeneration by TGFbeta1 through reducing inflammation and promoting VEGF-dependent angiogenesis. Biomaterials. 2012; 33:427787. | Article | PubMed

31. Santiago LY, Clavijo-Alvarez J, Brayfield C, Rubin JP and Marra KG. Delivery of adipose-derived precursor cells for peripheral nerve repair. Cell Transplant. 2009; 18:145-58. | Article I PubMed

32. Ma T, Gong K, Ao Q, Yan Y, Song B, Huang H, Zhang X and Gong Y. Intracerebral transplantation of adipose-derived mesenchymal stem cells alternatively activates microglia and ameliorates neuropathological deficits in Alzheimer's disease mice. Cell Transplant. 2013; 22 Suppl 1:S113-26. | Article | PubMed

33. Chen AZ, Liu N, Huang H, Lin FF, Liu DS and Lin XH. [Outgrowth of neuronal axons on adipose-derived stem cell transplanting for treatment of cerebral infarction in rats]. Xi Bao Yu Fen Zi Mian Yi Xue Za Zhi. 2011; 27:868-71. | PubMed

34. Bunge RP. The role of the Schwann cell in trophic support and 
Ghasemi et al. Journal of Histology \& Histopathology 2014, http://www.hoajonline.com/journals/pdf/2055-091X-1-12.pdf

regeneration. J Neurol. 1994; 242:S19-21. | Article | PubMed

35. Gulati AK, Rai DR and Ali AM. The influence of cultured Schwann cells on regeneration through acellular basal lamina grafts. Brain Res. 1995; 705:118-24. | Article | PubMed Abstract | PubMed Full Text

36. Jessen KR and Mirsky R. Schwann cells and their precursors emerge as major regulators of nerve development. Trends Neurosci. 1999; 22:40210. | Article | PubMed

37. Mahay D, Terenghi $G$ and Shawcross SG. Schwann cell mediated trophic effects by differentiated mesenchymal stem cells. Exp Cell Res. 2008; 314:2692-701. | Article | PubMed

38. Guenard V, Kleitman N, Morrissey TK, Bunge RP and Aebischer P. Syngeneic Schwann cells derived from adult nerves seeded in semipermeable guidance channels enhance peripheral nerve regeneration. J Neurosci. 1992; 12:3310-20. | Article | PubMed

39. Mosahebi A, Fuller P, Wiberg M and Terenghi G. Effect of allogeneic Schwann cell transplantation on peripheral nerve regeneration. Exp Neurol. 2002; 173:213-23. | Article | PubMed

40. Liao D, Gong P, Li X, Tan Z and Yuan Q. Co-culture with Schwann cells is an effective way for adipose-derived stem cells neural transdifferentiation. Arch Med Sci. 2010; 6:145-51. | Article | PubMed Abstract | PubMed Full Text

41. Zhang WC, Ding YJ, Cao JK, Du JX, Zhang GF and Liu YJ. Intracerebral cografting of Schwann's cells and fetal adrenal medulla in the treatment of Parkinson's disease. Chin Med J (Engl). 1994; 107:583-8. | Article | PubMed

42. Jiang CC, Xia Y, Ding ZL, Wang Y and Xu B. Effects of co-engraftment of Schwann cells with neural stem cells into rats with Parkinson disease. Chin Med J (Engl). 2006; 119:1030-3. | Article I PubMed

43. Woodhoo A, Sahni V, Gilson J, Setzu A, Franklin RJ, Blakemore WF, Mirsky $R$ and Jessen KR. Schwann cell precursors: a favourable cell for myelin repair in the Central Nervous System. Brain. 2007; 130:2175-85. | Article I PubMed

44. Yang L, Fang JS, Wang W, Chen RK and Shen CF. Transplantation of Schwann cells differentiated from adipose-derived stem cells modifies reactive gliosis after contusion brain injury in rats. J Int Med Res. 2011; 39:1344-57. | Article | PubMed

45. Kanno H, Pressman Y, Moody A, Berg R, Muir EM, Rogers JH, Ozawa H, Itoi $E$, Pearse DD and Bunge MB. Combination of engineered Schwann cell grafts to secrete neurotrophin and chondroitinase promotes axonal regeneration and locomotion after spinal cord injury. J Neurosci. 2014; 34:1838-55. | Article | PubMed Abstract | PubMed Full Text

46. Mantovani $C$, Terenghi $G$ and Shawcross SG. Isolation of adult stem cells and their differentiation to Schwann cells. Methods Mol Biol. 2012; 916:47-57. | Article | PubMed

47. Tomita K, Madura T, Sakai Y, Yano K, Terenghi G and Hosokawa K. Glial differentiation of human adipose-derived stem cells: implications for cell-based transplantation therapy. Neuroscience. 2013; 236:55-65. I Article I PubMed

48. Kaewkhaw R, Scutt AM and Haycock JW. Anatomical site influences the differentiation of adipose-derived stem cells for Schwann-cell phenotype and function. Glia. 2011; 59:734-49. | Article | PubMed

49. Kramer R, Zhang Y, Gehrmann J, Gold R, Thoenen H and Wekerle H. Gene transfer through the blood-nerve barrier: NGF-engineered neuritogenic T lymphocytes attenuate experimental autoimmune neuritis. Nat Med. 1995; 1:1162-6. | PubMed

50. Sadan O, Shemesh N, Barzilay R, Bahat-Stromza M, Melamed E, Cohen Y and Offen D. Migration of neurotrophic factors-secreting mesenchymal stem cells toward a quinolinic acid lesion as viewed by magnetic resonance imaging. Stem Cells. 2008; 26:2542-51. | Article | PubMed

51. Sadan O, Shemesh N, Barzilay R, Dadon-Nahum M, Blumenfeld-Katzir T, Assaf Y, Yeshurun M, Djaldetti R, Cohen Y, Melamed E and Offen D. Mesenchymal stem cells induced to secrete neurotrophic factors attenuate quinolinic acid toxicity: a potential therapy for Huntington's disease. Exp Neurol. 2012; 234:417-27. | Article | PubMed

52. Sadan $O$, Melamed E and Offen D. Intrastriatal transplantation of neurotrophic factor-secreting human mesenchymal stem cells improves motor function and extends survival in R6/2 transgenic mouse model for Huntington's disease. PLoS Curr. 2012; 4:e4f7f6dc013d4e. | Article | PubMed Abstract I PubMed Full Text

53. Sadan O, Bahat-Stromza M, Barhum Y, Levy YS, Pisnevsky A, Peretz H, Ilan AB, Bulvik S, Shemesh N, Krepel D, Cohen Y, Melamed E and Offen D. Protective effects of neurotrophic factor-secreting cells in a 6-OHDA rat model of Parkinson disease. Stem Cells Dev. 2009; 18:1179-90. | Article I PubMed

\section{Citation:}

Ghasemi N and Razavi S. Transdifferentiation potential of adipose-derived stem cells into neural lineage and their application. J Histol Histopathol. 2014; 1:12.

http://dx.doi.org/10.7243/2055-091X-1-12 